\title{
An Enduring Concept for Security Council Reform
}

\author{
Klaus Schlichtmann ${ }^{1,2}$ \\ ${ }^{1}$ Nihon University, Tokyo, Japan; ${ }^{2} J a p a n$ Women’s University, Tokyo, Japan. \\ Email: KSchlichtmann@law.email.ne.jp
}

Received March 20 ${ }^{\text {th }}, 2011$; Revised April 23 ${ }^{\text {rd }}, 2011$; Accepted May $18^{\text {th }}, 2011$.

\begin{abstract}
UN Security Council reform has been lingering over the years, since it was first seriously considered in the 1990s, after the collapse of the Soviet Union. This paper argues that enlarging the Security Council by adding new permanent and non-permanent members, while many of the Charter provisions vital for the maintenance of international peace and security and disarmament are not in effect, would be counterproductive. Instead, the composition of the Council should be reshuffled and expanded by giving a seat to a prominent member of the Global South, i.e. India, and replacing the seats of France and Britain with a single European representation. While there would be no increase or change in the number of permanent and non-permanent members, the result will be a dramatic increase in the numbers of people represented by the Permanent Five, which then will, in effect, comprise half of the world's population projected for 2012. The underlying logic is that increasing the number of permanent members (P5) would make the Security Council not only less effective, but also prevent the realization of a fundamental purpose of the United Nations, i.e. the transition from an armed to an unarmed peace. By maintaining the number 5, the effective operation of the consensus principle required for the maintenance of international peace and security during the transition is ensured. It is maintained that the changes proposed in this paper may be regarded as "purely procedural" under Article 27 paragraph 2 of the Charter. It will be seen, however, that to trigger the process of the transition, UN Member states (other than the P5, who bear responsibility under the Charter to guarantee safe passage during the transition) must begin, one by one, to delegate "Security Sovereignty" to the Council.
\end{abstract}

Keywords: Transitional Security Arrangements/Transition Period, Collective Security, Consensus Principle/Veto, Limitation/Delegation of Sovereign Powers, International Security, Disarmament

\section{Introduction}

In January 1992 newly elected UN Secretary-General Boutros Boutros-Ghali, famous for his "Agenda for Peace $^{1}[1]$," called a Security Council Summit meeting, where fifteen heads of state for the first time after the end of the Cold War reconfirmed their "commitment to collective security" and resolved to strengthen the United Nations, and for that purpose reform the Security Council. The UN Charter review process anticipated in Article 109, which had a similar aim, had never materialized in the early years of the Organization as originally anticipated, due to the Cold War. ${ }^{2}$

In 1993, the Open-ended Working Group on the Question of Equitable Representation on and Increase in the Membership of the Security Council and Other Matters Related to the Security Council was established. Reform

\footnotetext{
${ }^{1}$ UN Doc. A/47/277-S/24111 of 17 June 1992, An Agenda for Peace: Preventive diplomacy, peacemaking and peace-keeping. According to Boutros Boutros-Ghali, "during the whole cold war period, the question centered around the need to shore up the weak authority of the Council .. Today, the question has been turned on its head.”
}

proposals had to be in accordance with the conditions of more "equitable representation on and increase in the membership of the Security Council." (GA Res. 48/26 of December 3, 1993) On October 24, 1995, on the occasion of the 50th anniversary of the United Nations, the General Assembly unanimously declared the UNSC "should inter alia be expanded and its working methods continue to be reviewed in a way that will further strengthen its capacity and effectiveness, enhance its representative character, and improve its working efficiency and transparency." However, there has been no agreement so far [2], although great powers like Germany and Japan as well as African and South-American nations have been eager to be included as permanent members in an expanded Council.

\footnotetext{
${ }^{2}$ Article 109 foresaw a "General Conference" to be held "before the tenth annual session of the General Assembly" following the adoption of the Charter, for the purpose of review and possible amendments of the Charter under Article 108. The supposed intention was to put the Transitional Security Arrangements into effect. If so, the status of the permanent members of the Security Council was in fact not considered permanent.
} 
The question is: Does the wording necessarily imply that the Security Council must expand by increasing the number of individual nation-state members, or could "increase in the membership of the Security Council" also be taken to mean an increase in the number of states-like those joined in the EU-and the number of people represented? Foremost, isn't it "We, the Peoples of the United Nations" who are to be equitably represented, and who have a role to see that the principles of the United Nations are upheld and its purposes accomplished? The most important item on the agenda "Right of Peoples to Peace" [3-6] may be to see that the System of Collective Security, which the founders of the United Nations had envisioned, and which could guarantee that right, will put into effect. To achieve this, the composition of the Security Council needs to be only changed slightly, by reducing the two European seats to one and admitting a prominent member from the hitherto unrepresented Global South, i.e. India ${ }^{3}$ [7].

Because it is required for the transition from an armed to an unarmed peace [8], the consensus principle must be upheld. There is no other way to achieve disarmament and a stable peace ${ }^{4}$ [9-11], save succeeding generations from the scourge of war, steer clear of the insecurity brought about by the global arms trade and international organized crime, and avert the effects of financial crises and environmental degradation. In addition, the provisions in peace constitutions corresponding to the UN Charter, required to fulfill the high Purposes of the United Nations, must be implemented [12], and the provisions in the UN Charter, which have not yet been implemented, vital to maintaining international peace and security, be put into operation.

\section{The Case for UNSC Reform}

The United Nations Charter is the result of the meticulous, continuous efforts of lawyers, diplomats, governments and the peace movement since the Hague Peace Conferences first aimed at an organized, global peace. The Charter incorporated into international law an entirely new concept, i.e. the "transitional period." Already before and during World War I the Australian-German pacifist and 1911 Nobel Peace laureate Alfred Hermann Fried emphasized that it was necessary after war had ended not to return to an armed peace that merely perpetuates international anarchy but to an organized state

\footnotetext{
${ }^{3}$ It could be argued that the UN Charter set up some of the colonial powers as quasi-proxies, e.g. for a country like India. "When the UN was founded, few envisaged complete decolonization even in this century.”

${ }^{4}$ Among principles recognized as indispensable already in the Interwar Period are the following "three distinct sets of policies: the regulation of armaments, the pacific settlement of disputes, and collective action," which need to be put into practice.
}

subject to the rule of law. Fried rightly observed that while nation-states were

not nominally at war, and they appeared to be at peace ... in reality the condition was one of latent war, differing from acute war, where the guns are actually fired, only in degree and not in kind ... What we are experiencing with horror to-day [i.e. WWI] is only the conclusion of a process to which the present generation had become accustomed, the inevitable outcome of that condition of latent war which grew out of the lack of human adjustment to the natural course of evolution, and made anarchy dominant [13-15].

This idea did not materialize until it was incorporated in the UN Charter, which envisaged-as evinced in the analysis of the 1942 American Commission to Study the Organization of Peace planning for the future international organization-that, as political scientist Quincy Wright put it, "[a]fter the fighting is over and aggression has been suppressed, a period of reconstruction will be necessary to establish an order more adequate than the 'peace' which preceded and produced the hostilities. The problem is not to restore to an earlier situation but to build a more adequate world order." [16] However, this also has remained on paper only, so far $^{5}$ [17]

Politicians and international lawyers have done little to explicate the issue. One reason may be, as Mohammed Bedjaoui has pointed out, that the West has used international law to its own advantage, and tabooed objectives that would curtail state sovereignty. "Disguised as indifference or neutrality, it is in effect a permissive law intended for a liberal or neo-liberal world economy based on certain peoples' freedom to exploit others.” [18] However, the institution of the veto is not part of a 'neo-colonial conspiracy', as some people believe, but an essential ingredient required for the transition. Not surprisingly the great powers which had twice, in World War I and II, combined to suppress aggression and who created the League of Nations and the UN, were also put in charge of managing the proposed transition.

Evidently, the veto power, which became a tool of power politics during the Cold War, ${ }^{6}$ [19] is the reverse side of the consensus principle, required for the transition, an issue closely related to Chapter VII of the UN Charter,

\footnotetext{
${ }^{5}$ British author and pacifist H.G. Wells talked about a world authority or "Peace Council" which would "also be a permanent Disarmament Committee" that could "pool the military, naval, and air establishments of the federated nations into one international force, and proceed to reduce that force to the dimensions of a world police".

${ }^{6}$ Yet, it may also not be too far-fetched to say that the veto has contributed to averting a military showdown between the United States and Soviet Russia in the past half-century, perhaps as much as, if not more than, the policy of nuclear deterrence. "There is no direct evidence that nuclear weapons prevented a world war. Conversely, it is known that they nearly caused one... As for the assertion that nuclear weapons prevent wars, how many wars are needed to refute this argument?”
} 
i.e. enforcement action. ${ }^{7}$ [20] This will work only if the UN Security Council has no more than five permanent members. Apart from the fact that the number five is important for the effective functioning of their decision-making process, this arrangement ensures that the P5 will not war among themselves. It would not be desirable to "enforce peace" (Chapter VII of the Charter) by a majority vote. ${ }^{8}$ [21]

The main problem is how to trigger the process of the transition, so that the permanent members, plus, "as occasion requires ... other Members of the United Nations," (Article 106) ${ }^{9}$ [22] will be able to effectively guard the organized passage from "latent war" (Fried) to sustainable, perpetual peace ${ }^{10}$. To this effect the peace constitutions for empowering the United Nations are a key instrument. It is one of the disturbing aspects of power politics, supported by a military-industrial-academic complex, that this issue has been notoriously neglected, while the question of founding a global authority with enforcement powers to "transcend" and eventually abolish the institution of war remains the most important single issue that needs to be addressed by lawmakers, nongovernmental organizations (NGOs), academics, peace re-

\footnotetext{
${ }^{7} \mathrm{~A}$ consensus is required with respect to "military" enforcement action. "When I joined the United Nations in 1945, Chapter VII was the show ${ }^{8}$ piece of the Charter. It was called the 'teeth' of the Charter.”

This problem was clearly realized by some authors early on. Every Reves wrote: "If in a given situation, three of the major powers voted for a certain military intervention, while the other two voted against such a measure, these two powers could scarcely be pictured taking up arms and undertaking military action contrary to what they regard as their own national interests, and contrary to their votes. So the whole debate on unanimous vote versus majority vote... is irrelevant.” Emery Reves, The Anatomy of Peace, London and Toronto, Cassell, 1950, p, 213.

${ }^{9}$ Article 106 of the UN Charter states: "Pending the coming into force of such special agreements referred to in Article 43 as in the opinion of the Security Council enable it to begin the exercise of its responsibilities under Article 42, the parties to the Four-Nation Declaration, signed at Moscow, 30 October 1943, and France, shall, in accordance with the provisions of paragraph 5 of that Declaration, consult with one another and as occasion requires with other Members of the United Nations with a view to such joint action on behalf of the Organization as may be necessary for the purpose of maintaining international peace and security.” Interestingly, at the time of the Korean crisis in 1950, the Russians refused to sanction the actions of the United Nations in Korea, insisting on an "invocation or implementation" of Article 106. On 11 October 1950, the representative of the USSR submitted this resolution for the last time: "The General Assembly, Taking into account the particular importance of concerted action by the five permanent members of the Security Council in defending and strengthening peace and security among nations, Recommends that before armed forces are placed at the disposal of the Security Council under appropriate agreements concluded in accordance with Article 43 of the Charter, the five permanent members of the Security Council ... should take steps to ensure the necessary implementation of Article 106 of the Charter for the purpose of taking such joint action on behalf of the organization as may prove to be necessary for the maintenance of international peace and security."

${ }^{10}$ The McCloy-Zorin Agreement, unanimously adopted by the UN General Assembly on 20 December 1961, was such a plan for an organized passage from war to peace. Online:

http://www.nuclearfiles.org/menu/key-issues/nuclear-weapons/issues/
} arms-control-disarmament/mccloy-zorin-accords_1961-09-20.htm. searchers and activists.

Under the present circumstances, if the institution of war is not abolished and replaced by an equally powerful and persuasive system, it is unlikely that the world's political, social and economic problems will be solved. It is reasonable, therefore, to assume that the United Nations should obtain a monopoly of power and operate an international police force ${ }^{11}$ [23] to enforce international law and order and monitor disarmament. From the point-of-view of the transition, the composition of the permanent members, which reflected the political environment after the Second World War and rewarded the victorious powers, was never planned to be permanent, just as it was also not planned that the UNSC was to be above the law, "a law unto itself," as Mohammed Bedjaoui has written, with "no principles of law... laid down to guide it,"12 [24] lacking full legitimacy.

Since the United Nations has no sovereignty of its own, the comprehensive "system for the regulation of armaments” (Article 26, UN Charter), an essential ingredient in a system of collective security, has also so far remained on paper only [25]. An effectively functioning UN security system requires that member states "confer on the Security Council primary responsibility for the maintenance of international peace and security." (Article 24, UN Charter) So far, however, UN member states have not conferred onto the Security Council primary responsibility for the maintenance of international peace and security

in the sense of a sovereignty transfer. Something like that would presume that in that respect the states had positively removed a competence they had exercised up to now from within their own area of competence, and handed it over to the UN ... The Charter of the United Nations ... does not change the competence structure of nation-states, no more than any other international treaty. $^{13}$

But that is precisely what is required under the UN Charter. Pretending that there is already a System of Collective Security in place, while nation-states continue to maintain individual militaries, is counterproductive, and ultimately leads to war. So, in order to give effect to the provision, national lawmakers must pass legislation, giving the Security Council a much wanted code of conduct $^{14}$ and the power to be able to act promptly and effectively in order to maintain international peace and security, by delegating sovereign powers to it-apart from making available to the Security Council, under

\footnotetext{
${ }^{11}$ For early plans which eventually took shape in the UN Charter, see David Davies.

${ }^{12}$ That the Security Council was not intended to be "a law unto itself" was articulated by John Foster Dulles, War or Peace, New York, Macmillan, 1950, p. 194.

${ }^{13}$ Eminent Professor of international law Knut Ipsen in a written statement to the author (Letter of 13 April 1999).

${ }^{14}$ See Bedjaoui, The New World Order and the Security Council.
} 
Article 43, "armed forces, assistance, and facilities."15

Consistent with the international law concept of the transition period the Transitional Security Arrangements provide for-besides the P5—co-opting "other Members of the United Nations with a view to ... joint action" (Article 106) [26] during the passage from the present state of an armed to an unarmed peace. This well thought-out scheme would make countries like Germany, Japan and other troop-contributing countries eligible to take up key functions during the transition.

Assessing the situation, though somewhat late in the day, since the Russians under Mikhail Gorbachev had already in 1987 and later also in connection with the Gulf War in 1990 recommended deploying a common fleet under the United Nations flag and activating the UN Military Staff Committee [27]_objectives France and others had shared-former UN General-Secretary Boutros Boutros-Ghali, in his Agenda for Peace, stated:

11. We have entered a time of global transition marked by contradictory trends. Regional and continental associations of States are evolving ways to deepen cooperation and ease some of the uniquely contentious characteristics of sovereign and nationalistic rivalries. National boundaries are blurred by advanced communications and global commerce, and by the decisions of States to yield some sovereign prerogatives to larger, common political associations. At the same time, however, fierce new assertions of nationalism and sovereignty spring up, and the cohesion of States is threatened by brutal ethnic, religious, social, cultural or linguistic strife. Social peace is challenged on the one hand by new assertions of discrimination and exclusion and, on the other, by acts of terrorism seeking to undermine evolution and change through democratic means.

However, legally, and in actual fact, the transitional period has not even started.

Finally, the history and performance of ad-hoc UN peace-keeping operations (PKO) sanctioned by the United Nations Security Council (UNSC) is evidence of the usefulness and feasibility of international policing. ${ }^{16}$ [20] However, since PKO are based on special arrangements outside the Charter, this provision unwittingly supports the maintenance of national militaries, and is not supportive of attaining an unarmed, positive peace, as envisaged in the UN Charter. Considering the premise of a disarmed and organized world under the rule of law, UN Members have so far failed to take the necessary steps toward achieving this goal. As a consequence the $\mathrm{UN}$ is losing credibility, the arms trade and war continue

\footnotetext{
${ }^{15}$ A binding Disarmament Treaty or regulation under Article 26 of the UN Charter should take care of the problem of a peacekeeping organization turning into a warmaking enterprise.

${ }^{16}$ Somewhat overassertive Brian Urquhart, “After the Cold War: Learning from the Gulf", p. 9: "We are celebrating ... the actual application of the principle of collective security against aggression.”
}

unabated and disillusionment has set in among the "Peoples of the United Nations."

\section{A Chance Was Missed after the Fall of the USSR} Due to European Intransigence

At the beginning of the 1990s, a number of proposals were put forward to strengthen the United Nations and put the UN System of Collective Security into effect. For the first time the USA and Russia, the two allies in World War II, were reconciled. US President George Herbert Walker Bush in an address to the UN General Assembly on 1 October 1990 envisaged a United Nations "fulfilling its promise as the world's parliament of peace."17 [28] Russia, traditionally in favor of collective security, was upfront $[27,29]$. Germany announced it was aiming at a permanent representation for a "single European Union”, but subsequently did nothing to bring it about, in spite of French President François Mitterrand's broad hint in January 1992 that France was willing to share nuclear responsibility in Europe [30,31], implicitly agreeing to a European permanent representation in the UNSC. In a complementary proposal on 31 January 1992, at the already mentioned "first-ever" UN Security Council summit in New York, France offered 1000 French troops for a rapid deployment force at the Council's disposal, as a start [32], and, like Russia before, suggested "revitalizing the Military Staff Committee ${ }^{18}$ [33,34]." Nothing came of it, because already on 1 March 1993, former German Foreign Minister Dr. Klaus Kinkel maintained that "it would be unrealistic to imagine the European Community taking a seat on behalf of Europe

\footnotetext{
17،"This is a new and different world. Not since 1945 have we seen the real possibility of using the United Nations as it was designed-as a center for international collective security. The changes in the Soviet Union have been critical to the emergence of a stronger United Nations." "And, for the first time," Bush said, "the UN Security Council is beginning to work as it was designed to work."

${ }^{18}$ The Military Staff Committee in charge of the police function is placed at the disposal of the executive council, to "advise and assist" it, and to take on responsibility "for the strategic direction of any armed forces" under the authority of the Security Council. (UN Charter, Article 47, (1) and (3)) Shortly before the rift between the powers in 1947, it "submitted ... estimates of the overall strength required by the United Nations." In these, "the United Kingdom, the Soviet Union and China were all thinking in terms of a land army consisting of not more than 12 divisions; the highest estimate, that of the United States, was for 20 divisions. Similarly, the United Kingdom, the Soviet Union and China would have been satisfied with an international air force totaling not more than 1200 aircraft; the corresponding figures in the French and American estimates were 1275 and 3800. As regards naval forces, none of the five delegations proposed more than 3 battleships, 6 aircraft carriers, 15 cruisers, 84 destroyers and 90 submarines; the majority of them proposed a much smaller force.” UN Document S/394; see also Yearbook of the United Nations, 1947-1948, p. 495. "The United States subsequently revised its estimates downwards." However, whether the armed forces which are "to be 'placed at the disposal' of the Security Council can be properly described as an 'international police force' depends on the meaning" we give it. Politically it would mean "a permanent army of an international nature over and above national armies or even replacing them.” Statement by the Rapporteur of Committee III/3 of the San Francisco Conference at the opening meeting; UNCIO Document 134, III/3/3.
} 
on the Council."19 The rationale for blocking these initiatives by Germany is not clear, especially since the European Union was created "with a view to the achievement of political union.” The Treaty on European Union (Treaty of Maastricht) and similarly the Treaty of Lisbon unequivocally stipulate that the European Union shall "define and implement a common foreign and security policy ... to preserve peace and strengthen international security, in accordance with the principles of the United Nations Charter." ${ }^{20}$ Although the European Union is not a "state", it is a supranational organization with considerable powers of direct enforcement in the member States. Also, if it has been considered possible to have regional representation on a rotational basis for other regions, there is no reason to assume that a similar arrangement would not be feasible for Europe. Until Europe becomes a political union-and even if it does not ${ }^{21}$ - a legal construction should be found. ${ }^{22}$

In spite of their constitutional commitment to international organization (see Appendix), the Europeans have so far not been able to put their act together and answer the universal plea for outlawing war, disarmament and empowering the United Nations. ${ }^{23}$

\section{The Question of National Sovereignty}

"Every year that the Security Council continues with its present structure, the UN suffers because the increasingly apparent lack of representativeness of the council membership diminishes its credibility and weakens its capacity for conflict prevention.” (Carnegie Endowment for International Peace [35])

Already in 1955, the Russell-Einstein-Manifest, the starting point for the Pugwash movement, declared that the "abolition of war will demand distasteful limitations of national sovereignty..."24 Yet Nation states are reluc-

\footnotetext{
${ }^{19}$ 'Germany to push for UNSC Seat', The Japan Times, March 1, 1993. According to the paper, Foreign Minister Kinkel enigmatically declared that in that case "Germany would have to amend its constitution."

${ }^{20}$ Treaty on European Union of January 1, 1993, Final Act and Title I, Common Provisions, Article B. Similarly, the German Constitution, in its Preamble, stipulates the purpose "to serve the peace of the world as an equal part in a unified Europe.” However, the more recent Treaty of Lisbon does not mention collective security, and disarmament only once.

${ }^{21} \mathrm{~A}$ very good idea would be to have a rotating European representation shared by France, Britain, Germany, Italy and Poland for example.

${ }^{22}$ As a step in this direction, recently, the EU has been given the privilege of a single representation in the UN General Assembly. GA/11079/ Rev. 1, vote of 3 May 2011.

${ }^{23}$ On the history of the war outlawry movement in the interwar period that resulted in the Kellogg-Briand Pact see for example Hans Wehberg, The Outlawry of War, a series of lectures delivered before the Academy of International Law at The Hague and in the Institut Universitaire de Hautes Etudes Internationales at Geneva, Washington, Carnegie Endowment for International Peace, 1931.

${ }^{24}$ However, if nation-states agree to limitations of their national sovereignty, according to the Manifest, "there lies before us, if we choose, continual progress in happiness, knowledge and wisdom. Shall we instead, choose death, because we cannot forget our quarrels?” For the Russell/Einstein Manifesto, commonly known as the Pugwash Manifesto, see www.pugwash.org/about/manifesto.htm.
}

tant to give up any part of their national sovereignty for fear of becoming vulnerable and appearing weak. Nevertheless, "restriction of nation state sovereignty ... (remains an) indispensable item on any reform agenda ... It is also the most important item, since without this restriction no other reforms designed to make the UN more effective in realizing its professed goals can be meaningful.” [36]

The realization was not confined to the West. The late Indian president and philosopher, Professor Sarvepalli Radhakrishnan, expressed the same idea:

We must surrender a part of our sovereignty, work together for the elimination of every kind of injustice ... The United Nations is the first step towards the creation of an authoritative world order. It has not got the power to enforce the rule of law ... Military solutions to political problems are good for nothing. Ultimately they will leave bitterness behind ... The challenge that is open to us is survival or annihilation ... but what are we doing to bring about that survival? Are we prepared to surrender a fraction of our national sovereignty for the sake of a world order? Are we prepared to submit our disputes and quarrels to arbitration, to negotiation and settlement by peaceful methods? Have we set up a machinery by which peaceful changes could be easily brought about in this world? So long as we do not have it, it is no use merely talking [37].

In neighboring Pakistan as well a similar sentiment had been expressed. At the Conference of the Interparliamentary Union (IPU) in 1952, the Pakistani diplomat Ahmed E.H. Jaffer stated:

The evils of the sovereign state and its incapacity to maintain peace are increasingly felt ... In my opinion time is ripe for beginning to plan and shape organizations which will ultimately form the nucleus of world federation ... in connection with the question of limits to state sovereignty discussed at this conference it has been made amply clear that one of the greatest impediments to real political and economic cooperation between the states is the sovereignty of states and that the remedy for the sufferings of mankind lies in curtailing and limiting that sovereignty [38].

Even a realist such as Robert Strausz-Hupe, founding member of the U.S. Foreign Policy Research Institute, in 1992 made the following statement before a U.S. Commission on Improvement of the Effectiveness of the United Nations:

What is needed first and foremost in order to make the United Nations more effective and viable is candor. The peoples of the world need to be told that a more effective United Nations comes at a price and that this price is the delegation of national sovereignty; in the beginning, not all of it, but as the process continues, more and more of it [39].

China, too, has not been averse to this kind of organ- 
izational pacifism. H.G. Wells the pacifist early on called for China to become "a pillar of ... world civilization equivalent to the ... English-speaking world," and contribute to the peace and order of the world. [40] Indeed, Mozi (about 470-391 BCE), the pacifist philosopher in the early period of the Warring States, who called for restrictions of the sovereign power to fight aggressive war, is held in high esteem even among the Communist leadership. And whether present-day mainland Chinese like it or not, Madame Chiang Kai-shek for one had a good understanding concerning the purposes and principles of the future United Nations, when she stated: "The term 'hands and feet' is often used in China to signify the relationship between brothers. Since international inter-dependence is now so universally recognized, can we not also say that all nations should become members of one corporate body?,"25 [41,42] Some similar statements, favoring international organization, have also been ascribed to Mao Zedong.

Not surprisingly, more recently, at the UN Summit meeting in New York in September 2005, Chinese President Hu Jintao stressed the necessity to "strengthen Collective Security Mechanism[s]" and "improve the Council's efficiency so as to respond to threats more effectively," as well as "improve the Council's decision making by giving greater expression to democratic principles." $26 \mathrm{Hu}$ emphasized that the "Security Council needs a capability of rapid response,"27 an allusion, no doubt, to Article 43 of the UN Charter.

However, the rapidly changing security environment and continuing reluctance of the European nations to agree to limitations of their national sovereignty in favor of the international rule of law, poses obvious dangers. Old-timer Henry Kissinger, in a keynote address on 10 September 2010, at the International Institute for Strate-

\footnotetext{
${ }^{25}$ On 18 February 1943. Chiang Kaishek himself, “a friend of Indian self-determination,” and Mahatma Gandhi agreed on many points when they met in Calcutta in February 1942.

${ }^{26} 2005$ Position Paper of the People's Republic of China on the United Nations Reforms, calling for a "reformed UN with a bigger role to play that will serve the common interests of humanity" and the establishment of "an effective, efficient and fair collective security mechanism." http://www.fmprc.gov.cn/eng/wjb/zzjg/gjs/gjzzyhy/2594/2602/t199318. htm. The UN Permanent Five Summit Document issued on 15 November 2000, proclaiming the P5's “commitment to ensuring that the UN is stronger, more effective and more efficient than ever before as it enters the 21st century."

http://www.fmprc.gov.cn/eng/wjb/zzjg/gjs/gjzzyhy/2594/2602/t15216.ht $\mathrm{m}$

${ }^{27}$ Most recently there has been a move both by China and the USA to cooperate with the Russian Commonwealth's Collective Security Treaty Organization (CSTO), e.g. in Kyrgyzstan. Similar statements, calling for "strengthening collective security" have come from disarmament negotiator Hu Xiaodi. "The international community should give up the idea, to try to obtain security superiority by military means,” he said. Website of the Peoples Republic of China in Vienna, statement of 6 October 2005:

http://www.chinaembassy.at/det/xwdt/t215208.htm (translated from the German; statement no longer available online!)
}

gic Studies in Geneva, warned that Collective Security as an ideal to be realized any time soon was losing ground, because the support "to organize an effective global collective security system on many key issues, including nuclear proliferation,” was lacking. ${ }^{28}$

The issue was highlighted by UN Secretary-General Kofi Annan in his 2004 Report of the High-level Panel on Threats, Challenges and Change, A more secure world: Our shared responsibility: "The United Nations was never intended to be a utopian exercise. It was meant to be a collective security system that worked.” (p. 4) Though the Report mentions "collective security" more than a hundred times, it did not address the problem of limiting nation-state sovereignty, although it did point out that "[w]hatever perceptions may have prevailed when the Westphalian system first gave rise to the notion of State sovereignty, today it clearly carries with it the obligation of a State to protect the welfare of its own peoples and meet its obligations to the wider international community.” (p. 17)

The famous "war-abolishing" clause in the Japanese Constitution, Article 9, limiting state sovereignty, professes to achieve this purpose, i.e. an "international peace based on justice and order." Article 9 reads:

Aspiring sincerely to an international peace based on justice and order, the Japanese people forever renounce war as a sovereign right of the nation and the threat or use of force as a means for settling international disputes. -In order to accomplish the aim of the preceding paragraph, land, sea, and air forces, as well as other war potential will never be maintained. The right of belligerency of the state will not be recognized. (Constitution of 3 May $1947[43,44])$

The reason why the end of the Cold War had not more quickly "opened the way to a cooperative security system that would minimize the role of armed force in international affairs" [45] is to be found in the inability of nation-states to pool their interests in this vital area. Naturally, this step requires a break from traditional military security and a bold leap over the national shadow. Friedrich Nietzsche, in his Human, All too Human, in the Chapter "The Wanderer and his Shadow," pointed out "the means to real peace" more than a hundred years ago:

No government nowadays admits that it maintains an army so as to satisfy occasional thirsts for conquest; the army is supposed to be for defence. That morality which sanctions self-protection is called upon to be its advocate. But that means to reserve morality to oneself and to accuse one's neighbour of immorality... This is how all states now confront one another: they presuppose an evil

\footnotetext{
28، The drift regarding proliferation will, within a measurable point, oblige the international system to choose whether to take decisive measures-however defined-or to live in a proliferated world." Online http://www.henryakissinger.com/speeches/091010.html
} 
disposition in their neighbour and a benevolent disposition in themselves. This presupposition, however, is a piece of inhumanity as bad as, if not worse than, a war would be; indeed, fundamentally it already constitutes an invitation to and cause of wars... The doctrine of the army as a means of self-defence must be renounced just as completely as the thirst for conquest...-As is well known, our liberal representatives of the people lack the time to reflect on the nature of man: otherwise they would know that they labour in vain when they work for a gradual reduction of the military burden [46].

Limitation of national sovereignty with regards to the right to go to war addresses the root cause of the problem. If war is to be abolished, ${ }^{29}$ nation states must delegate sovereign powers to the United Nations Security Council, to give the United Nations proper executive powers. ${ }^{30}$ [47] The international community is duty-bound to give the Council a basic law. A "Bill" in the Parliament of some able nation transferring "security sovereignty" (Professor Ian Tinbergen ${ }^{31}$ ) would initiate the process of defining the Security Council's powers, and at the same time trigger the transition from an armed to an unarmed peace. In Germany, parliament may pass such bill with simple majority under Article 24 of the Federal Republic of Germany's Basic Law. ${ }^{32}$ (See APPENDIX) [48]

The Japanese Constitution's Article 9 points a way out of the dilemma, aiming as it does at the abolition of war; seen as a motion to be seconded it would open the debate on the issue, e.g. in the UN General Assembly. Nations do not have to simultaneously pool sovereign powers with the United Nations, to bring about an effective system of collective security; if only one adept and well endowed UN Member state starts the process, owing to the principle of reciprocity, an obligation erga omnes arises, $[49,50]$ and all others are bound to follow.

\section{Article 9-a way to banish war?}

The abolition or outlawry of war had become a major foreign policy objective with and after the First World War. The Japanese diplomat Shidehara Kijûrô (18721951), who had been following a conciliatory policy toward China and the other powers as Foreign Minister between 1924 and 1932, was a chief player in the international political arena. He was known as an internation-

\footnotetext{
${ }^{29}$ This is the aim of the Hague movement, “Appeal for Peace 1999,” and of Pugwash: "The only way to prevent it (the ultimate nuclear catastrophe) is to abolish war altogether.” Joseph Rotblat in his speech on the occasion of receiving the Nobel Peace Prize on behalf of Pugwash.

${ }^{30}$ Reviewing the legality of the Council's actions, as suggested in some. quarters, to "help build up a body of rules concerning the question of competence [of the UNSC], based on the opinion of the highest legal authority under the Charter," would be desirable.

${ }^{31}$ Professor Jan Tinbergen in a personal letter to the author on June 7, 1985: "I think it is an excellent idea to have transferred security sovereignty from national governments to the Security Council of the United Nations..."

${ }^{32}$ It was clear at the time that this referred to the United Nations. "We must come to such organizations, otherwise we are busted," Carlo
}

alist and a pacifist, had been on the list of judges to the Permanent Court of Arbitration at The Hague from 1918-24, negotiated disarmament at the Washington Naval Conference in 1921-1922, and prior to that had closely monitored the Hague Peace Conferences. There is sufficient evidence to believe that Shidehara as one of the first post-World War II Prime Ministers suggested Article 9 of the Japanese Constitution (JC) to General Douglas MacArthur on January 24, 1946 [51-53].

In fact, the origin of Article 9 and other constitutional provisions limiting state sovereignty in favor of international organization can be traced, if not to The Hague, to a Resolution by the 22nd Conference of the Interparliamentary Union (IPU) held in Bern in 1924:

The XXIInd Inter-Parliamentary Conference endorses the stipulation ... voted at the Fourth Assembly of the League of Nations, by the terms of which war of aggression is described as an international crime, and recommends that proposals be submitted ... to ... parliaments for amendments to the Constitution, such proposals a) to forbid resort to war ... [and] b) to make arbitration or other amicable or judicial means obligatory [54].

As the German parliamentarian professor Walther Schücking pointed out at the IPU Conference, "wars could then only be declared, if the constitution is revised at the same time.,33 [54,55]

International lawyers and national lawmakers were working together to "harmonize" domestic law with the evolving international law of peace. The above proposal engaged lawmakers around the world, when Shidehara, Aristide Briand, Frank Kellogg and Gustav Stresemann were foreign ministers. Subsequently, progressive international lawyers and some governments continued to envisage the outlawing of war in national constitutions. ${ }^{34}$ $[55,56]$ Hans Wehberg, renowned international jurist and editor of the famous journal "Die Friedens-Warte" (The Peace Watchtower) until 1962 (still in existence), had already pointed out during the interwar period, in a series of lectures delivered before the Academy of International Law at The Hague and in the Institut Universitaire de Hautes Etudes Internationales at Geneva that "it seems desirable to outlaw war in the constitutions of the various states as soon as possible and without awaiting the elaboration of an ideal international pact ... The provision, whereby wars of aggression are constitutionally prohibited and wars of defense and of sanction can be decided upon only by a qualified majority of the legislative organs, would be of immense importance.” [57]

\footnotetext{
${ }^{33}$ There were other events where the quest was confirmed: in 1929 in Athens, Greece, at the XXVII. Conference of the International Peace Bureau (IPB, Bern), following the conclusion of the Paris Peace Pact (Kellogg-Briand), an IPB Resolution called on the signatories to "amend their constitutions" to make recourse to the pacific settlement of disputes obligatory.

${ }^{34}$ See Mirkine-Guetzevitch for the most in-depth analyses.
} 
This trend was pursued after 1945. The following provision in the Danish constitution was based on recommendations by another IPU Conference held in Bern from 28 August to 2 September 1952:

Art. 20. Powers which according to this constitution rest with the authorities of the kingdom, can, through a bill, to a specifically defined extent, be transferred to international authorities, which are instituted by mutual agreement with other states to promote international legal order and cooperation [58].

In this light, the Japanese Constitution's Article 9, ${ }^{35}$ [59] aiming at the abolition of war and an "international peace based on justice and order" became a cornerstone for a future "international legal order and cooperation." Article 9 is a motion to abolish war among nations, which could trigger the process of the transition, and bring the issue of the abolition of war into open debate, if it is followed up.

Corresponding to the Danish Article 20 and to Article 9 of the Japanese Constitution, a number of constitutions provide for limiting national sovereignty, for the purpose of international cooperation and peace. (See APPENDIX) The frequency of these provisions in the constitutions of Europe suggests that the solution of this problem was given high priority. Law-makers wanted to facilitate Europe's integration into the world community, and strengthen the international organization of peace.

We must think carefully about how to effectively strengthen world organization, to avert another total war in future. Regional integration and international organization must go hand in hand. In fact, regional integration will be much enhanced by strengthening the international legal order first, as some diplomats and international jurists had seen clearly, early on in the twentieth century. ${ }^{36}$ [60] At the Inter-Parliamentary Union conference in 1952 at Berne, the Indian participant rightly pointed out that

The two world wars have taught Europe that national sovereign states could not be the last word in the evolution of human civilization ... What we require now is a world organization which will be authorized with the rights surrendered by other states ... The civilized nations

\footnotetext{
${ }^{35}$ In the 1950s discussions on constitutional revision took place on a large scale in Japan, and the question of limitations of national sovereignty was carefully studied. Japanese scholars proposing to revise Article 9 considered amendments to the Japanese Constitution, suggesting that its limitation of sovereignty be based on conditions of reciprocity, as in the Danish, French, Greek and Italian constitutions. The proposal of the Association for Constitutional Studies (kempô kenkyû-kai), published on 23 May 1956, contained the following revised Article 9 (Article 117): "Japan, under condition of reciprocity with other states, agrees to limitations of its sovereignty, which are necessary for the organization of international peace and its safeguarding.”

36 "In 1912 the German jurist Schücking was perhaps the first to emphasize that the European powers ... had extra-European interests that were too important to permit them to establish a union that was limited to Europe.”
}

have failed in the case of the League of Nations, and I may not be quite wrong if I say the Locarno Pact was the first step leading to that failure. I have my own misgivings as to whether many of these European political organizations are not in a way neutralizing the effectiveness of the United Nations. [61]

The Pakistani delegate concurred:

I personally feel that regional confederation of states or the creation of regional representative assemblies would have the effect of delaying the process of establishing a world Parliament or a world State, because regional super-states or assemblies would in the nature of things develop a sense of rivalry among themselves, and instead of co-operating with each other would run into conflict, very much like the modern sovereign state. [61]

Divergent national and regional military establishments will not be able to effectively maintain international peace and security in the twenty-first century. If the military establishments are not abolished, the best scenario (short of another total war) is George Orwell's 1984, a sincere warning for humanity.

\section{India and the "Skillful Surgeon" Approach}

A skillful surgeon will try to obtain the maximum result with the least effort, keeping to a minimum the incisions required to remove the affected parts or make implants and cure the patient [62]. Since (1) Europe is overrepresented, and (2) the Global South is not represented at all, the aim must be to obtain a single European (EU) representation $^{37}$ [63] and place a capable and experienced representative of the Global South, i.e. India, in the vacant seat. ${ }^{38}$ [64] This could possibly be carried out as a procedural matter. Contesting candidates for the UNSC would be liable to agree if it is made clear to them that this arrangement will be for the transition period only. The necessary global paradigm shift may be accomplished within the scope of the UN Charter, and with little change either in the text of the Charter or the composition of the Security Council. Yet the results would be decisive and awesome.

Since 2005 India’s bid to become a UNSC permanent

\footnotetext{
${ }^{37}$ A European Security Council seat had been the goal of American foreign policy early on. See Congressional Record, April 22, 1947, A1905, for "identical resolutions... introduced by Messrs. Fulbright and Thomas in the Senate and Hale Boggs in the House, the substance of which was that America favored the creation of a United States of Europe within the framework of the United Nations Charter (emphasis added). That resolution was subsequently adopted."

${ }^{38}$ The US administration has issued the following criteria concerning the required qualifications for permanent members: "size of economy and population, military capacity, contributions to peacekeeping operations, commitment to democracy and human rights, financial contributions to the United Nations, non-proliferation and counter-terrorism records, and geographic balance.”
} 
member also has also gained the support of China. ${ }^{39}$ [65] India is the world's most populous democracy, comprising almost one sixth of the world population. Its Muslim population also is a factor to be reckoned with. According to an estimate, "more than half of the world's citizens living under democratic rule are to be found in South Asia.” [66] Historically, India has been the country credited most frequently with a tradition of non-violence and pacifism. It has propounded universalist principles and philosophy, ${ }^{40}$ [67] and assumed a leading role among the developing and non-aligned countries. However, as France and Britain will most likely agree to a single European representation only, if the UN System of Collective Security is put into effect, China, too, ideally would under the same condition agree to an Indian permanent representation.

India, allegedly possessing the world's third largest army and the fifth-largest navy in terms of personnel, [68] is a major "troop-contributing country" to the United Nations. She is a factor of stability, because unlike Pakistan she is basically self-contained. While Pakistan, a major arms exporter, poses a problem in the region, there also seem to be a number of convergent interests and issues between the two countries ${ }^{41}$ [69] as reflected in SAARC. Cooperation between India and other Asian countries, such as China and Japan, on issues of disarmament, monitoring, and the abolition of war will have a positive impact on the region, and the world. While Pakistan had for a long time attempted to acquire nuclear capability [70], and apparently possessed nuclear weapons for some time before India, ${ }^{42}$ India has for a long time been a proponent of nuclear disarmament, and has in the past advocated a world federal authority ${ }^{43}$ [71-73] complementing some idealistic American and European foreign policy objectives in the twentieth century. ${ }^{44}$

There is a basic tendency in democracies to submit to

\footnotetext{
${ }^{39}$ India together with Russia and the U.K. had early on also supported Communist China to be represented in the United Nations prior to its admission as a permanent member in 1971.

${ }^{40}$ Amartya Sen claims that "a tendency towards unity and a broad synthesizing priority are very special characteristics of Indian culture.” ${ }^{41}$ India and Pakistan at least "in the short run may be able to expand their peacekeeping and stabilizing role in regions adjacent to South Asia."

${ }^{42}$ Apparently already in 1993 its nuclear weapons program had been developed to the point of enabling Pakistan to assemble a nuclear weapon.

${ }^{43}$ Prime Minister Jawaharlal Nehru stated in a speech broadcast in the United States: "I have no doubt that world government must and will come, for there is no other remedy for the world's sickness. The machinery for it is not difficult to devise. It can be an extension of the federal principle, a growth of the idea underlying the United Nations, giving each national unit freedom to fashion its destiny according to its genius."

${ }^{44}$ See the Resolution in both Houses, H.Con.Res.64 and S.Con.Res.56, of June 7, and July 26, 1949 respectively, calling for the "development" of the United Nations "into a world federation open to all nations with defined and limited powers.”
}

the rule of law on a global scale. But does the fact that India has become a nuclear power mean that it has abandoned its basic philosophy of and disposition toward nonviolence and UN support and is no longer eligible? Most likely not. [74] Since India could not agree with the argument that the commitment under Article VI of the Nuclear Non-Proliferation Treaty (NPT) "only requires negotiations and not necessarily the conclusion of a treaty to abolish nuclear weapons” and bring about general and complete disarmament under strict and effective international control, a reasonable "bargain of disarmament and non-proliferation ... continues to remain unfulfilled." [75] However, the above "misperception and misinterpretation was set at rest," according to Jasjit Singh, former director of New Delhi's renowned Institute for Defense Studies and Analyses (IDSA), by the ICJ's 1996 ruling concerning the legality of nuclear weapons, in which the judges unanimously agreed that "there exists an obligation to pursue in good faith and bring to a conclusion negotiations leading to nuclear disarmament in all its aspects under strict and effective international control. ${ }^{45}$ [76] Under these circumstances India's strategy had been "to keep the nuclear option open as long as feasible, not weaponize, and work for disarmament which would eliminate the roots of the security dilemma., ${ }^{46}$ [75] Eventually circumstances forced India to take actionand also share the blame.

Cooperation with Pakistan and other neighbors could facilitate the implementation of a practical policy of peace and disarmament in the area and beyond. India could greatly advance her aspirations and cause, if she would take such responsibility upon herself, for the sake of world peace, as a permanent representation in the UNSC would entail..$^{47}[77,78]$ As it is, still, the present state of "warlessness simply means the indefinite postponement of a nuclear war", while "in a generic sense the term 'warlessness"” should refer to a "world situation in which disarmament has been achieved, decisions of the International Court of Justice are enforceable, an international police force has been established effectively, and the veto has been abolished in the Security Council," [79] following the transition.

\section{The New Security Council}

The "pragmatic dream" [80] of an effective global foundation of peace requires a feasible plan. However, in spite of the fact that already a century ago "the industrial

\footnotetext{
${ }^{45}$ In the Preamble to the Non-Proliferation Treaty "the cessation of the manufacture of nuclear weapons," and "the liquidation of all existing stockpiles" are stipulated.

46،"It was mostly ignored or not understood in the Western world that an open option was a policy of restraint.”

${ }^{47}$ The mishaps of the interwar period should not happen again, e.g. when Japan was not trusted or taken seriously, in spite of the conciliatory Shidehara Kijûrô, who was foreign minister in the twenties. At that time chances for cooperation and peace were squandered and missed.
} 
and technical advances ... made the world interdependent in a sense previously undreamt of ... adjustment to the changed conditions" has been incremental, although "[t]he dream of romantic war ... ended" long ago. [81] The UNSC must be restructured, to include a prominent member of the Global South. The new permanent members should immediately take up their responsibilities to formulate "plans for the establishment of a system for the regulation of armaments" (Article 26, in connection with Article 47, UN Charter), with a view to achieving UN-controlled "general and complete disarmament", and embark on the transition to a positive peace, based on law, instead of military power sustained by competing nation-states. ${ }^{49}$ The 1961 McCloy-Zorin Accords are a formidable precedent toward this end.

Can this be achieved? French political scientist and geo-politician Dominique Moisi has rightly observed: "Things have to change quite radically if the international order is not to collapse into a profound and dangerous disequilibrium.” Political leaders have to understand that to maintain the present "status quo is a recipe for disaster." To bring about peaceful change we have "to reinvent the concept of sovereignty for the twenty-first century.” [82]

As already stated, the Charter revision to accommodate India and reduce the two European seats to a single representation could very well be dealt with as a procedural matter under Article 27 paragraph 2 of the Charter-similar to when the People's Republic of China replaced Taiwan as a permanent member. Giving India a permanent seat in the Security Council would not only positively affect the regional environment, but also strengthen the global framework for peace and security, as well as help achieve general and comprehensive disarmament under strict international control, ${ }^{50}$ [83] while bringing together more than half of the world's population represented by the P5 alone.

\section{Acknowledgements}

\footnotetext{
${ }^{48}$ The President of the Nuclear Age Peace Foundation, David Krieger, has pointed out, that "the regulation of armaments [under Article 26 of the UN Charter] is not optional for the Security Council. The Article says unambiguously that the Security Council 'shall' formulate such a plan. The members of the Security Council have breached a solemn duty to the people of the world... the United Nations can succeed only if the nations that are its members live up to their legal duties under the Charter.” David Krieger, 20 May 1996, http://www.globalpolicy.org SECURITY COUNCIL. However, it seems the Security Council can formulate such plan only after Members have conferred on it primary responsibility for fulfilling the task.

${ }^{49}$ “'The UN Charter offers a far more appropriate framework for relations among nations ... than does the doctrine of power politics."

${ }^{50}$ Robert McNamara has pointed out some time ago, an "important element in a global collective security system would be strengthening existing regional organizations such as the Organization of American States and the Organization of African Unity, as well as the creation of such groups in Asia and the Middle East. These bodies would eventually function as regional arms of the UNSC.”
}

I thank Professor Alfred de Zayas for having read and commented upon my manuscript.

\section{REFERENCES}

[1] B. Boutros-Ghali, "Preface,” In: M. Bedjaoui, "The New World Order and the Security Council, Testing the Legality of Its Acts,” Martimus Nijhoff, Dordrecht, 1994, p. 17.

[2] B. Fassbender, "On the Boulevard of Broken Dreams. The Project of a Reform of the UN Security Council after the 2005 World Summit," International Organizations Law Review, Vol. 2, No. 12, 2005, pp. 391-402. doi:10.1163/157237405775093708

[3] The United Nations General Assembly, "The Declaration on the Right of Peoples to Peace,” Approved by General Assembly Resolution 39/11 of 12 November 1984.

[4] “The Luarca Declaration: A Legal Response, Guaranteeing the Right to Peace through the United Nations System."

http://alfreddezayas.com/Law_history/Luarca_Declaratio n_English_revised\%5B1\%5D.pdf

[5] “The Declaration of Santiago de Compostela.” Adopted on 10 December 2010.

http://www.aedidh.org/?q=node/1853

[6] A. de Zayas, "Peace as a Human Right. The jus cogens Prohibition of Aggression,” In: C. V. Duran, Ed., Contribuciones Regionales Para un Derecho Universal del Derecho Humano a la Paz, Asociacion Española parael Derecho Internacional de los Derechos Humanos, Luarca, 2010, pp. 157-174.

[7] E. Childers and B. Urquhart, "Reviewing the United Nations System,” Dag Hammarskjold Foundation, Uppsala, 1994.

[8] Carnegie Endowment for International Peace, Commission to Study the Organization of Peace, "Second Report-The Transitional Period," International Conciliation, No. 379, April 1942.

[9] A. Martin, "Collective Security. A Progress Report," United Nations Educational, Scientific and Cultural Organization, Paris, 1952, p. 36.

[10] F. P. Walters, “A History of the League of Nations,” Oxford University Press, London, 1960, p. 228.

[11] F. P. Walters, "Legal Aspects of Disarmament,” International and Comparative Law Quarterly, Vol. 7 (Supplement), 1963, pp. 1-133.

[12] K. Schlichtmann, “Article 9 in Context—Limitations of National Sovereignty and the Abolition of War in Constitutional Law,” The Asia-Pacific Journal, Vol. 23-6-09, 8 June 2009. http://www.japanfocus.org/-Klaus-Schlichtmann/3168.

[13] A. H. Fried, “The Restauration of Europe,” MacMillan, New York, 1916.

[14] A. H. Fried, "Die Grundlagen des Revolutionären Pazifismus," The Foundations of Revolutionary Pacifism, Tübingen, 1908. 
[15] D. Senghaas, “On Perpetual Peace: A Timely Assessment,” Berghahn Books, New York, 2007.

[16] Q. Wright, "Political Conditions of the Period of Transition: Commission to Study the Organization of Peace," International Conciliation, No. 379, 1942, pp. 265-266.

[17] H. G. Wells, "After Democracy: Addresses and Papers on the Present World Situation,” Watts \& Co., London, 1931.

[18] M. Bedjaoui, "Towards a New International Order," Holmes \& Meier, New York, 1979.

[19] J. Rotblat, "Remember Your Humanity," Speech on the Occasion of Receiving the Nobel Peace Prize, 1995. http://www.pugwash.org/award/Rotblatnobel.htm.

[20] B. Urquhart, "After the Cold War: Learning from the Gulf,” Brown University, Providence, 1991.

[21] E. Reves, "The Anatomy of Peace," Cassell, London, 1950.

[22] Extracts Relating to Article 106 of the Charter of the United Nations, "Repertory of the United Nations Organs,” Repertory of Practice (1945-1954), Vol. 5, p. 381. http://untreaty.un.org/cod/repertory/art106/english/rep_ori g_vol5-art106_e.pdf\#pagemode=none

[23] D. Davies, "The Problem of the Twenty-First Century, A Study in International Relationships,” Ernest Benn, London, 1930.

[24] M. Bedjaoui, "The New World Order and the Security Council, Testing the Legality of Its Acts," Martimus Nijhoff, Dordrecht, 1994.

[25] B. Urquhart and R. McNamara, "Toward Collective Security: Two Views,” The Thomas J. Watson Jr. Institute of International Studies, Brown University, Occasional Papers No. 5, March 1991.

[26] T. M. Cooperstein, "Article 106 of the United Nations Charter,” Texas Review of Law \& Politics, Vol. 11, No. 2, 2007, pp. 353-374.

[27] R. Dore, “Japan, Internationalism and the UN," Routledge, London, 1997.

[28] G. Bush, “The UN: World Parliament of Peace,” Address before the United Nations General Assembly, US Department of State Dispatch, New York, 1 October 1990.

[29] “US and Soviets as Allies. First Time since 1945," The headline in the New York Times, Vol. 7, August 1990.

[30] T. Daley, “Can the UN Stretch to Fit the Future?” The Bulletin of the Atomic Scientists, Vol. 48, No. 3, 1992, pp. 38-42.

[31] P. Zaylor, “France Might Share Its Bomb,” Japan Times, 15 January 1992.

[32] H. P. Langille, "Conflict Prevention: Options for Rapid Deployment and UN Standing Forces," In: O. Ramsbotham and T. Woodhouse, Eds., Warlords, Hawks and Doves: Peacekeeping as Conflict Resolution, Frank Cass Publishing, London, 2000, Note 11.

[33] L. M. Goodrich, E. Hambro and A. P. Simons, "Charter of the United Nations, Commentary and Documents,” 3rd Revised Edition, Columbia University Press, New York, 1969.
[34] B. Fassbender, "Review Essay-Quis Judicabit? The Security Council, Its Powers and Its Legal Control,” International Journal of Innovation and Learning, Vol. 11, No. 1, 2000, p. 231.

[35] Carnegie Commission, "Preventing Deadly Conflict, Final Report," Carnegie Corporation, New York, December 1997.

[36] A. Rapoport, "Foreword," In: E. Fawcett and H. Newcombe, Eds., United Nations Reform-Looking Ahead after Fifty Years, Science for Peace, Toronto, 1995, p. 11.

[37] S. Radhakrishnan, “Towards a New World,” Orient Paperbacks, New Delhi, 1980.

[38] Statement of the Pakistani Delegate Mr. A. E. H. Jaffer, "XLIst Inter-Parliamentary Conference, Compte Rendu de la XLIe Conférence tenue a Berne du 26 août au 2 septembre 1952,” Bureau Interparlementaire, Geneva, 1952, pp. 777-779.

[39] J. Logue, “Introduction,” In: M. J. Adler, Ed., How to Think about War and Peace, Fordham University Press, New York, 1995, pp. 26-27.

[40] “China: The Land out of the Limelight,” In: H. G. Wells, Ed., A Year of Prophesying, MacMillan, New York, 1925, p. 221.

[41] "War and Peace Aims," Extracts from Statements of United Nations Leaders: Special Supplement No. 2 to the United Nations Review, United Nations Information Office, New York, 1 December 1943, p. 76.

[42] P. F. Power, "Gandhi on World Affairs,” George Allen \& Unwin, London, 1961.

[43] C. M. Overby, K. Masao and M. Kazuma, "A Call for Peace. The Implications of Japan's War-Renouncing Constitution,” Kodansha International, Tokyo, 1997.

[44] T. McNelly, "General Douglas MacArthur and the Constitutional Disarmament of Japan," The Transactions of the Asiatic Society of Japan, 3rd Series, Vol. 17, 1982, pp. 1-33.

[45] R. Forsberg, "Keep Peace by Pooling Armies,” The Bulletin of the Atomic Scientists, March 1992, p. 41.

[46] F. Nietzsche, "Human, All too Human-A Book for Free Spirits," In: R. J. Hollingdale, Ed., "The Wanderer and His Shadow,” Vol. II, Part two, Cambridge University Press, Cambridge, 1996, pp. 380-381.

[47] M. Bedjaoui, "The New World Order and the Security Council, Testing the Legality of Its Acts," Martimus Nijhoff, Dordrecht, 1994.

[48] "Der Parlamentarische Rat 1948-1949, Akten und Protokolle,” Bd.2-Der Verfassungskonvent auf Herrenchiemsee (Documents and protocols, Vol. 2, The Constitutional Convention at Herrenchiemsee), Deutscher Bundestag und Bundesarchiv, Bonn, 1975/1981, p. 454.

[49] R. O. Keohane and L. L. Martin, "The Promise of Institutionalist Theory,” International Security, Vol. 20, No. 1, 1995, p. 50. doi: $10.2307 / 2539214$

[50] R. O. Keohane, "Reciprocity in International Relations," 
International Organisation, Vol. 40, No. 1, 1986, pp. 1-27. doi:10.1017/S0020818300004458

[51] K. Schlichtmann, "Japan in the World. Shidehara Kijûrô, Pacifism and the Abolition of War," Lanham, New York, 2009.

[52] Schlichtmann, "The Ethics of Peace: Shidehara Kijûrô and Article 9 of the Constitution,” Japan Forum, Vol. 7, 1995, pp. 43-67.

[53] Schlichtmann, "A Statesman for the Twenty-First Century? The Life and Diplomacy of Shidehara Kijûrô (1872-1951)," Transactions of the Asiatic Society of Japan, Vol. 4, No. 10, 1995, pp. 33-67.

[54] Union Interparlementaire, "Compte Rendu de la XXIIe Conférence Tenue a Berne et Genève du 22 au 28 Août 1924,” Librairie Payot, Genève, 1925, pp. 666 and 422.

[55] M. Guetzevitch, "Le Droit Constitutionnel et L'organisation de la Paix (Droit Constitutionnel de la Paix)," Recueil des Cours, Vol. 3, No. 45, 1933, p. 741.

[56] M. Guetzevitch, "La Renonciation à la Guerre dans le Droit Constitutionnel moderne," Revue Héllenique de Droit International, Vol. 4, 1951, pp. 1-16.

[57] H. Wehberg, “The Outlawry of War," Carnegie Endowment for International Peace, Washington DC, 1931, p. 115.

[58] S. V. Anderson, “Article Twenty of Denmark's New Constitution," The American Journal of International Law, Vol. 50, No. 3, 1956, pp. 654-659.

[59] W. Röhl, “Die japanische Verfassung,” Metzner, Frankfurt, 1963.

[60] F. H. Hinsley, "Power and the Pursuit of Peace: Theory and Practice in the History of Relations between States," Cambridge University Press, Cambridge, 1963.

[61] XLIst Inter-Parliamentary Conference, Compte Rendu, pp. 652, 654, 778.

[62] K. Schlichtmann, "A Draft on Security Council Reform," Peace \& Change, Vol. 24, No. 4, 1999, pp. 505-535. doi:10.1111/0149-0508.00135

[63] A. J. Zurcher, "The Struggle to Unite Europe, 19401958,” New York University Press, New York, 1958.

[64] Statement in the UNGA, US Mission to the UN Press Release, Vol. 130, No. 5, 12 July 2005, In: Fassbender, Ed., “On the Boulevard of Broken Dreams,” p. 401.

[65] Carnegie Endowment for International Peace, "China and the United Nations,” Manhattan Publishing, New York, 1959.

[66] S. P. Cohen, "The United States, India, and Pakistan: Retrospect and Prospect," Association for Clinical Documentation Improvement Specialists Occasional Paper, July 1997, p. 1.

[67] A. Sen, “On Interpreting India’s Past,” The Asiatic Society, Calcutta, 1996.

[68] A. H. Cordesman and M. Kleiber, "Overview of Major Asian Powers. Working Draft for Review and Comment," Center for Strategic and International Studies, 26 June 2006. http://csis.org/files/media/csis/pubs/060626_asia_balance _powers.pdf

http://www.globalsecurity.org/military/world/india/navy-i ntro.htm

[69] S. P. Cohen, “The United States, India, and Pakistan,” p. 10.

[70] Congressional Record, "Nuclear and Missile Proliferation,” Senate, 16 May 1989, pp. S5437-S5449. http://www.fas.org/spp/starwars/congress/1989/890516-cr .htm

[71] “Pandit Nehru's Discovery of America,” Foreword by Eleanor Roosevelt, The Indian Press Publications, Madras, p. 56.

[72] “World Federation,” In: Indian National Congress’s Famous, Quit-India Resolution, 8 August 1942.

[73] K. Schlichtmann, "Mahatma Gandhi and the Quest for an Effective United Nations Organization, The Stakes, 1917-1947,” Gandhi Marg, Vol. 26, No. 1, 2004, pp. 55-81.

[74] K. Schlichtmann, "Has Indian Negotiating Power, to Achieve an International Order Based on Justice and the Rule of Law, Increased since the 1998 Nuclear Tests?” In: A. D'Souza and C. D'Souza, Eds., World Constitutionalism, Cambridge Scholars, Newcastle, 2007, pp. 198-206.

[75] J. Singh, "India, Europe and Non-Proliferation: Pokhran II and after," Strategic Analysis, Vol. 22, No. 8, 1998, p. 1112. doi:10.1080/09700169808458869

[76] Communiqué of International Court of Justice, "Legality of the Threat or Use of Nuclear Weapons," Advisory Opinion, Vol. 96, No. 23, 8 July 1966, p. 226.

[77] K. Schlichtmann, "Perceptions on Japan and the 'Versailles-Washington System' (Berusaiyu-Washinton Taisei) with Comments on Japan among Imperialist Powers in Asia/Pacific and Her Experiment with the Universal Principle of Racial Equality," Sophia International Review, Vol. 20, 1998, pp. 83-90.

[78] K. Schlichtmann, "Japan, Germany and Shidehara Diplomacy,” Journal of International Studies, Vol. 41, 1998, pp. 1-19.

[79] M. Kumar, "Current Peace Research and India,” Gandhian Institute of Studies, Varanasi, 1968.

[80] B. Urquhart, "After the Cold War: Learning from the Gulf,” Toward Collective Security, p. 15.

[81] A. H. Fried, “The Restauration of Europe,” MacMillan, New York, 1916.

[82] D. Moisi, "The Geopolitics of Emotion. How Cultures of Fear, Humiliation and Hope Are Reshaping the World," The Bodley Head, London, 2009.

[83] R. S. McNamara, "The Post-Cold War World and Its Implications for Military Expenditures in Developing Countries,” World Book, Washington DC, 1991. 


\section{Appendix}

\section{Peace Provisions in European Constitutions:}

AUSTRIA: By law or by a State Treaty which must be ratified in accordance with Article 50 (1), specific sovereign rights of the Bund can be transferred to intergovernmental institutions and their organs and the activity of organs of foreign status in Austria as well as the activity of Austrian organs abroad can be regulated within the framework of International Law. (Article 9, paragraph 2, of the Constitution as amended July 1, 1981).

BELGIUM: The exercises of given powers may be conferred by a pact or law on institutions coming under international civil law. (Article 25 bis, of September 29, 1971).

DENMARK: Powers which according to this constitution rest with the authorities of the kingdom, can, through a bill, to a specifically defined extent, be transferred to international authorities, which are instituted by mutual agreement with other states to promote international legal order and cooperation. (Article 20, of June 5, 1953).

FRANCE: On condition of reciprocity, France accepts the limitations of sovereignty necessary for the organization and defense of peace. (Preamble of the Constitution of October 27, 1946, stands reconfirmed in Constitution of 4 October 1958).

GERMANY: (1) The Federation may by legislation transfer sovereign powers to international organizations. ... (2) With a view to maintaining peace the Federation may become a party to a system of collective security; in doing so it shall consent to such limitations upon its sovereign powers as will bring about and secure a peaceful and lasting order in Europe and among the nations of the world. ... (Article 24 of the Constitution of May 23, 1949).

GREECE: To serve an important national interest and promote cooperation with other states authorities may be vested by a convention or agreement in agencies of an international organization. A majority of three fifth of the total number of members of Parliament shall be necessary to vote the law sanctioning the treaty or agreement. III. Greece shall freely proceed by law voted by the absolute majority of the total number of members of Parliament, to limit the exercise of national sovereignty, insofar as this is dictated by an important national interest, does not infringe upon the rights of man and the foundations of democratic government and is affected on the basis of the principles of equality and under condition of reciprocity. (Article 28 II., Constitution of June 7, 1975).

IRELAND: For the purpose of the exercise of any executive function of the State in or in connection with its external relations, the Government may to such extent and subject to such conditions, if any, as may be deter- mined by law, avail or adopt any organ, instrument or method of procedure used or adopted for the like purpose by the members of any group or league of nations with which the State is or becomes associated for the purpose of international cooperation in matters of common concern. (Article 29 IV, 20, originally of July 1, 1937).

ITALY: Italy renounces war as an instrument of offense to the liberty of other peoples or as a means of settlement in international disputes, and, on conditions of equality with other states, agrees to the limitations of her sovereignty necessary to an organization which will ensure peace and justice among nations, and promotes and encourages international organizations constituted for this purpose. (Article 11 of Constitution of January 1, 1948).

LUXEMBOURG: The exercise of the powers reserved by the Constitution to the legislative, executive and judiciary may be temporarily vested by treaty in institutions governed by international law. (Article 49 A., of Constitution of October 17, 1968, as amended on July 10, 1973).

THE NETHERLANDS: The Government shall promote the development of the international rule of law. (Article 90) ... Legislative, executive and judicial powers may be conferred on international institutions by or pursuant to a treaty... (Article 92 of the Constitution of February 17,1983$)$.

NORWAY: In order to secure international peace and security, or in order to promote international law and order and cooperation between nations, the Storting may, by a three-fourth majority, consent that an international organization, of which Norway is or becomes a member, shall have the right, within a functionally limited field, to exercise powers which in accordance with this Constitution are normally vested in the Norwegian authorities, exclusive of the power to alter this Constitution. For such consent as provided above at least two-thirds of the members of the Storting - the same quorum as is required for changes in or amendments to this Constitution - shall be present and voting... (Article 93 of the Constitution of May 17, 1814 as revised on 18 September 1905).

PORTUGAL: Portugal commends the abolition of all forms of imperialism, colonialism and aggression; general, simultaneous and controlled disarmament; the dissolution of political-military blocs and the establishment of a system of collective security, in order to create an international order capable of assuring peace and justice in relations among peoples. (Article 7 II., of April 25, 1976).

SPAIN: By means of an organic law, authorization may be established for the conclusion of treaties which attribute to an international organization or institution the exercise of competencies derived from the constitution. It is the responsibility of the Cortes Generals or the Government, depending on the cases, to guarantee compli- 
ance with these treaties and the resolutions emanating from the international or supranational organizations who have been entitled by this cession. (Article 93 of Constitution of December 29, 1978).

SWEDEN: The right to make decisions which under the present Instrument of Government devolves o the Riksdag, on the Government, or on any other organ referred to in the Instrument of Government, may be entrusted, to a limited extent, to an international organization for peaceful cooperation of which Sweden is to become a member, or to an International Tribunal. No right to make decisions in matters regarding the enactment, amendment, or repeal of a fundamental law or [to restrict] any of the freedoms and rights referred to in Chapter 2 may thus be transferred. The Riksdag shall decide on a transfer of the right to make decisions in the manner prescribed for the fundamental laws, or, if a decision in accordance with such procedure cannot be abided, by way of a decision agreed upon by not less than five-sixth of those present and voting and by not less than threefourths of the Riksdag members. (Chapter 10, Article 5, of 1809 as amended in 1976).

SWITZERLAND: The entry into organizations of collective security or supranational entities is subject to a vote by the people and the Cantons. (Article 89 V., of 1982). 